\title{
Competition Law and Policy Harmonisation: Its Relation to Fair Competition Realisation in ASEAN Single Aviation Market
}

\author{
A. A. B. N. A. Surya Putra* \\ Faculty of Law, Leiden University, the Netherlands \\ Article Received: 30th May 2019; Accepted: 24th July 2019; Published: $3^{\text {st }}$ July 2019

\begin{abstract}
A well-functioning ASEAN Single Aviation Market Requires a level-playing field and fair competition. ASEAN does not have a multilateral agreement on competition related issues but opts to harmonise its Member States' domestic legislation. This article asks whether this approach is appropriate to realise fair competition in ASEAN Single Aviation Market. It finds that mere harmonisation of laws and policies is insufficient without being complemented by effective implementation and enforcement. While regional enforcement is the ideal way of preventing and opposing unfair competition, this article also proposes the adoption of the concept of international comity as an achievable alternative to currently unequal ASEAN competition laws or the absence thereof.
\end{abstract}

Keywords: ASEAN; Aviation Market; Fair Competition; Harmonisation; Enforcement.

How to cite (Chicago 16th): Surya Putra, A. A. B. N. A., " Competition Law and Policy Harmonisation: Its Relation to Fair Competition Realisation in ASEAN Single Aviation Market" Udayana Journal of Law and Culture 3, no. 2 (2019): 164-183. https://doi.org/10.24843/UJLC.2019.v03.i02.p03.

doi: https://doi.org/10.24843/UJLC.2019.v03.i02.p03

\footnotetext{
*Email/Corresponding Author: suryaputra.aabna@gmail.com and a.a.b.n.a.surya.putra@umail.leidenuniv.nl
} 


\section{Introduction}

The Association of Southeast Asian Nations (ASEAN), ${ }^{1}$ as a regional organisation, has set out on a mission to create a stable, prosperous, economically integrated and highly competitive single market with effective facilitation for trade and investment. ${ }^{2}$ Its attempt to realize this mission is marked by the establishment of the ASEAN Economic Community (AEC) which has been launched and set to be effective since $2015 .{ }^{3}$

As put forward by academics, professionals, and observers, the establishment of AEC must be complemented by a culture of market competition, whether business is conducted domestically or regionally. ${ }^{4}$ However, in order to successfully create the ideal condition, ASEAN has to adopt competition law and policy. As of now, ASEAN is still struggling to harmonise the competition laws of its Member States. One of the obstacles is that neither all Member States nor ASEAN have competition laws. The second obstacle is its practice of only making non-binding policy by standing on the principle of non-interference.

Conversely, over the past two decades, ASEAN's focus on economic integration has encompassed the aviation sector. The ASEAN Single Aviation Market (ASAM), based on three types of multilateral agreement: The Multilateral Agreement on Air Services (MAAS); Multilateral Agreements on Full Liberalisation of Air Freight Services (MAFLAFS); and Multilateral Agreements on Full Liberalisation of Passengers Air Services (MAFLPAS), have become fundamental components of the AEC. Not only is aviation the most efficient mode of transportation to connect the Member States, it has a significant economic impact. ${ }^{5}$ The liberalisation of the aviation sector, which includes market access up to full third, fourth, and fifth freedoms of air traffic, as well as the relaxation of ownership and control rules, has made ASEAN aviation a prospective competitive field for undertakings and, not to mention, a sensible destination for foreign investment. ${ }^{6}$ In spite of that, without well-composed or uniform competition laws in the region and its enforcement, ASAM might as well stimulate anticompetitive practices and

1 ASEAN consists of ten Member States: Brunei Darussalam, the Kingdom of Cambodia, the Republic of Indonesia, Lao People's Democratic Republic, Malaysia, Myanmar, the Republic of Singapore, the Kingdom of Thailand, the Philippines, and Vietnam.

2 The 2008 Charter of the Association of Southeast Asian Nations (hereafter the ASEAN Charter'), Art. 1(5).

3 ASEAN. "Bali Concord II," http://www.asean.org/news/asean-statementcommuniques/item/declaration-of-asean-concord-ii-bali-concord-ii-3.

${ }^{4}$ Udin Silalahi, "The Harmonization of Competition Laws towards the ASEAN Economic Integration," 10 J. E. Asia \& Int'1 L. (2017): 118; Udin Silalahi, "Accelerating the Development of ASEAN Competition Culture", XII:2 L. Rev. (2012): 243; See also Burton Ong, The Regionalisation of Competition Law and Policy within the ASEAN Economic Community (Cambridge: Cambridge University Press, 2018).

${ }^{5}$ Adli Amirullah, "Economic Benefits of ASEAN Single Aviation Market", Institute for Democracy and Economic Affairs, Policy No. 56 (2018): 6.

6 Ibid.: 7. 
unreasonable compliance costs for undertakings, ${ }^{7}$ which in the end would result in a dysfunctional internal market.

This paper aims to scrutinise the harmonisation of competition laws and policies attempted by ASEAN and what impact it has on ASAM, which is expected to be fully realised in 2025. Subsequently, this paper questions whether the current regime of harmonisation is sufficient to achieve fair competition in ASAM. In answering the aforesaid problems, this paper will discuss the current competition law regime in ASEAN, which comprises of discussions on competition laws of ASEAN Member States and the attempt to harmonise their laws. Following that, the discussion will then continue to how international aviation society defines fair competition, with special reference to European Union (EU) law as an example of successful aviation market convergence at the region level. Further, this paper will draw on analysis of the existing legal regimes and propose ways to establish fair competition in ASAM before finally delivering concluding remarks.

The research methodology used in this paper is a normative legal research, including studies of literature on legal principles, systematics, vertical and horizontal synchronisation, history, and comparative law. ${ }^{8}$ This research method assesses issues originating from norms in legal instruments or the lack thereof in relation to aviation market competition in the AEC. The sources used vary from written international legal instruments, binding or non-binding, doctrine and domestic legislations, as well as court decisions.

\section{Result and Analysis}

\subsection{Overview of ASEAN Member States' Competition Laws}

ASEAN Member States can be divided into three categories with regard to competition laws: (i) Member States that have adopted a competition law regime in the previous decades including the current one; (ii) Member States that adopt a purist competition regime and Member States that adopt a mixed regime; (iii) Member States that have their competition laws set in terms of their applicable scope and Member States with laws that are silent with regards to competition.

\subsubsection{Time Gaps in the Implementation of Competition Laws by ASEAN Member States}

Countries like Indonesia, Singapore, Thailand, and Vietnam have implemented competition laws and policies. Respectively, those laws are amongst others: the Indonesian Law Number 5 of 1999 on the Ban of Monopolistic Practices and Unfair Business Competition, Singaporean Competition Act of 2005, the Thai Trade Competition Act of 1999, and Vietnamese Competition Law No. 27 of 2004. Each law establishes competition authorities that ensure the full implementation of competition laws in their respective countries. Indonesia has a Commission for Supervision of Business Competition (KPPU), Singapore has the Competition

${ }^{7}$ Huong Ly Luu, "Regional Harmonization of Competition Law and Policy: An ASEAN Approach." Asian Journal of International Law 2, no. 2 (2012): 291-321.

${ }^{8}$ Soerjono Soekanto and Sri Mamudji, Penelitian Hukum Normatif, Suatu Tinjauan Singkat, Jakarta: Raja Grafindo Persada, 2007. 12. 
Commission of Singapore, Thailand has a Trade Competition Commission, and Vietnam has the Vietnam Competition Authority for investigative purposes and the Vietnam Competition Council that serves as an adjudicator.

In the beginning of this decade, Malaysia enacted its Competition Act of 2010, establishing the Malaysia Competition Commission the following year. Brunei, Myanmar, and the Philippines have just enacted their competition laws in the last four years that bring into being their respective competition authorities. The Lao People's Democratic Republic (PDR) has passed its Competition Law of 2016. Cambodia is still drafting its competition law. ${ }^{9}$

Because of these time differences in implementation, the character of competition laws amongst the Member States show polarity. On one side the competition laws of some Member States act as a stand-alone law, which only regulate competitiveness in the market. But on the other side, the competition law regime of some Member States encompasses other aspects of trade.

\subsubsection{The Purists v. the Mixed Competition Regimes in the Region}

It is by no means the purpose of this analysis to suggest that one regime is better than another. It should be noted, however, that these differences may result in challenges for undertakings to comply with ASEAN competition law regimes in respective Member States. Whilst the mixed regime of competition law provides not only the maintenance of competitive markets but also includes other trade law elements such as protection against restrictive trade practices, consumer protections, etc., the purist regime chooses to disregard the latter. ${ }^{10}$

The different takes on competition regimes is considered to be organic since different countries seek to address different economic issues via competition laws. Indonesia, Myanmar, Thailand, and Vietnam adhere to the mixed regime, whereas Brunei, Malaysia, Singapore, and the Philippines have purist regimes.

\subsubsection{The Jurisdictions of Competition Laws in ASEAN Member States}

All competition laws and laws in the region provide provisions to control mergers and acquisitions (M\&A), prevent abuse of market dominance and cartels. ${ }^{11}$ However, there are differences as to what extent, in terms of jurisdiction, the competition laws can be enforced. Brunei, Cambodia, Malaysia, the Philippines, Singapore and Thailand adopt the extraterritorial application of their competition laws, commonly referred to as the 'Effects

9 Kingdom of Cambodia Nation Religion King. Draft Law on Competition of $\begin{array}{lll}\text { Cambodia. } & \text { Version } & 5.7 . \\ \text { competition.org/file/pdf_file/Draft\%20Law\%20on\%20Competition\%202018.pdf }\end{array}$

10 Ong, The Regionalisation of Competition Law and Policy within the ASEAN Economic Community, 82; See also Peter Freeman, "Is Competition Everything," Competition Law Journal 7, no. 3 (2008): 214-225

11 Devi Lucy Y. Siadari and Koki Arai, "International Enforcement of ASEAN Competition Law." Journal of European Competition Law \& Practice 9, no. 5 (2018): 328-335. 
Doctrine', providing that the anticompetitive action done by foreign undertakings outside their territory affect their economy. In contrast, Indonesia, Lao PDR, and Vietnam can only apply their competition laws if foreign undertakings conduct their businesses within their territory. ${ }^{12}$ As of now, there are no specific guidance or provisions in the competition law of Myanmar regarding its jurisdiction. ${ }^{13}$

\subsubsection{The Pathway and Determination to Harmonise}

These differences surely present challenges to ASEAN in its attempt to have the competition laws of its Member States harmonised. The first is that the organisation has to deal with how the Member States that have just enacted their competition laws keep up with the pace of other Member States that have implemented their competition laws in decades gone by. Secondly, the divergent scopes of competition laws in each Member State will present a challenge to the formulation of competition rules and, lastly, differences in jurisdiction would also present a problem of its own. Nevertheless, as it has been mandated by AEC, the region shall have its competition laws harmonised to better provide assurance for a common market. Moreover, the presence of giant developing nations, including China and India, is considered to be putting economic pressure on ASEAN. ${ }^{14}$ Then again, ASEAN is determined to have harmonised competition laws and policies despite having polarities in the three categories substantiated above.

\subsection{The Attempt to Harmonise Polarities}

To say that ASEAN is attempting to harmonise the polarity of competition laws in the region might be an oversimplification. Differences in jurisdiction and age gaps in competition regimes are not the only obstacles faced by ASEAN. The legal systems of the member States greatly differ. They range from civil law to common law, or a hybrid of the two traditions. 15 However, in view of these obstacles, the region is still moving to harmonise its constituent competition law regimes.

Harmonisation of competition law aims to adjust national laws to set guidelines rather than substituting them with a supranational law. ${ }^{16}$ In the process of achieving a single market, wherein political and legal discourse on liberalisation have influence, harmonisation is usually considered as 'setting [a] similar standard'. ${ }^{17}$ Since the conclusion of the 2007 ASEAN

12 The Law of the Republic of Indonesia Number 5 of 1999, Art. 1(5).

13 Devi Lucy Y. Siadari and Koki Arai, "International Enforcement of ASEAN Competition Law," 331.

14 Ong, The Regionalisation of Competition Law and Policy within the ASEAN Economic Community, 35; See also Tajul Ariffin Masron, "Promoting Intra-ASEAN FDI: The Role of AFTA and AIA", Economic Modelling 31 (2013): 43-48.

15 Ridha Aditya Nugraha, State Aid for Pioneer Routes Under PSO in Indonesia Against the Tide within ASEAN Open Skies?, (Mauritius: Lambert Academic Publishing 2017), 81.

16 Andrew Klip and H. van der Wilt, Harmonisation and harmonising measures in criminal law (van Wetenschappen: Royal Netherlands of Science 2002), 1.

17 Laura Spitz, "The Gift of Enron: An Opportunity to Talk about Capitalism, Equality, Globalization, and the Promise of a North-American Charter of Fundamental Rights", Ohio State Law Journal, 66(2) (2005) 315; see also David W Leebron, "Lying Down 
Charter, in the pursuit to narrow polarities, ASEAN has been attempting to set similar standards for competition regimes in the region by establishing ASEAN Expert Group on Competition (AEGC), as well as adopting AEC Blueprints and sector specific competition rules in ASAM. Through these instruments, Member States commit to completing and implementing competition laws.

\subsubsection{ASEAN Expert Group on Competition}

In August 2007, the Member States established a network of competition authorities, which has been the forum for stakeholders, scholars and competition experts from Southeast Asia. Its primary goal is to work on capacity building related to competition and assist with technical matters. One of its products is the ASEAN Regional Guidelines on Competition Policy ("the Competition Guidelines"), which targets various audiences from authorities to business players and consumers. ${ }^{18}$

ASEAN has also been organising and taking part in capacity building programmes with competition authorities from third countries and international organisations such as the Organisation for Economic Cooperation and Development (OECD), the International Competition Network, and the United Nations Conference on Trade and Development (UNCTAD).

The above-mentioned efforts have been considered by scholars in the region as the head start to competition law and policy harmonisation before AEC blueprints were concluded. The first AEC blueprint subsequently readdressed and reaffirmed the commitment of ASEAN Member States to lift differences and uncertainty of market competition in the region.

\subsubsection{ASEAN Economic Community Blueprints}

Upon its conclusion in November 2007, the 2015 Blueprint identified the introduction of competition policies in all Member States' as a necessary measure to establish a competitive market for the AEC. Additionally, the Blueprint also mandated ASEAN to establish a forum to discuss competition-related matters; encourage capacity building programmes; and develop regional guideline for competition. At the time of its conclusion, only four Member States had implemented competition laws. Mid-way through the plan, Malaysia implemented its competition law in 2011, leaving only five other Member States without competition laws. By the end of the term for this blueprint, Brunei, Myanmar, Lao PDR, and the Philippines passed their competition laws, marking nine Member States with competition laws.

The 2025 AEC Blueprint is most recent instrument for the AEC that includes commitments related to competition. Member States, pursuant to this blueprint, have agreed to continue to work on where they left off, as well as to set new strategic measures, among others: creating competition enforcement cooperation agreements to deal with cross-border commercial

with Procrustes: an Analysis of Harmonization Claims" in Jagdish Bhagwati and Robert Hudec, Fair Trade and Harmonization: Economic Analysis (Cambridge: The MIT Press 1996) vol $1,41$.

18 Casse Lee \& Yoshifumi Fukunaga, "ASEAN Regional Cooperation on Competition Policy." Journal of Asian Economics, 35 (2014): 77-91. 
transactions; developing a strategy on regulatory convergence; maintaining the ASEAN approach to competition law and policy in the region; and considering international best practices to further enhance a single competition regime between ASEAN Member States.

As the result, the AEGC released its ASEAN Competition Action Plan 2025 (ACAP 2025) that has been serving as a guide to direct, or rather give suggestions, to Member States. ACAP 2025 provides details on the strategic framework intended to set outcome expectations of competition law and policy reform from 2016 to 2025 .

\subsubsection{Step-by-step Harmonisation}

Taking a closer look to the way ASEAN ensures that all Member States have competition laws, the approach taken by ASEAN is a step-by-step one. Rather than setting standards all at once by means of multilateral agreements, ASEAN allows Member States to work on their respective competition law regimes by themselves. This approach has been accommodated in ACAP 2025, which sends ASEAN on a quest to: establish effective competition regimes in all Member States; strengthen the capacity of agencies related to competition in order to effectively implement competition laws and policies; advance the regional cooperation agenda by concluding cooperation agreements; foster a competition-aware region; and move towards greater harmonisation of competition laws and policies. ${ }^{19}$

Rather than enforcing a set of regional competition rules, ACAP 2025 started out with the predication to harmonisation that all ASEAN countries enact generic competition laws. Then it continued to ensure that by 2017, all competition laws and laws related to competitions are officially available in English to facilitate understanding. A set of in-house tools for competition agency staff is also set to be developed in the same year, whilst also preparing handbook for stakeholders every two years. The list of steady objectives per annum goes on. However, there are some most notable steps that really shows the commitment of ASEAN to harmonising competition rules.

The first is the set of goals put forward in 2018. In an effort to establishing cooperation agreements on competition, ASEAN seeks to have common elements, guidelines, and principles on competition. A strategy paper on regional convergence of competition laws is also set to be developed. Subsequently, this year, ASEAN is expected to develop an enforcement mechanism to handle cross-border cases. Such enforcement is established by a network of competition authorities in ASEAN Member States, which have their staff in an exchange programme with other Member State competition authorities to increase familiarity on how competition law works in each State. The last one is probably the most ambitious amongst other steps, that is, drafting agreed principles on competition by 2022 and having it endorsed in ASEAN by 2025.

Although not all of the annual goals will go as planned, like the goal to have all Member States enact competition laws by 2016, it is exhilarating to see the affirmative steps being set and taken up to realise what ASEAN has

19 ASEAN Secretariat, ASEAN Competition Action Plan 2025, 2. 
agreed to pursue. At the same time as the effort to harmonise competition laws to ensure a well-functioning AEC, one of the AEC sectors has seen a leap in the beginning of the second term of the ASEAN Blueprint. Air transport has been considered important to connect the region and has been developed together with AEC. The liberalisation agreements applicable to this sector, which have been ratified by all Member States, also bring a specific competition regime to cater to the specific needs of this newly liberalised market.

\subsection{The Air Transport Sector and ASEAN Competition Regime}

As one specific sector of the AEC, air transport contributes to serve as the bridge in the air connecting people and goods within the region. Airlines can now enjoy more routes enabled by the three agreements establishing ASAM briefly mentioned in the introduction. Airlines will also be allowed to receive more foreign investment, at least those with majority shareholders amongst nationals of ASEAN Member States. Thus, this newly liberalised sector also needs an effectively maintained competitive marketplace. Provisions obligating Member States to ensure fair and equal opportunity to compete in the single aviation market and to take action to eliminate all forms of discrimination and anticompetitive practices, either by States or airlines, are provided in all ASAM agreements. However, what ASAM does not provide is the mechanism to enforce those competition clauses. ${ }^{20}$

\subsection{Steadily Pacing towards Harmonisation}

To summarise the discussion in this chapter, all polarities of competition laws of ASEAN Member States are steadily being alleviated by composing non-binding instruments to avoid resistance from Member States. ASEAN comforts Member States with its step-by-step approach to harmonisation. It has to be admitted that non-binding guidelines would not be sufficient in the long term to protect the liberalised internal market, which is why a plan to formulate common principles on market competition has been set in motion. As the AEC has more than one sector, the sector playing the role of connecting people within the region is also being liberalised. With this market comes its own set of concern for competition. However, since air transport is considered to have a specific economic character, before discussing about the competition provisions in ASAM, the following chapter will discuss the international legal framework of competition as applied in air transport.

\subsection{Numerous Regime with Identical Characteristics}

Not limited to aviation sector, competition laws differ from State to State with no unified international regulations. ${ }^{21}$ But although there are various regimes, there are identical characteristics of competition law. As

20 Pablo Mendes de Leon, "Competition in International Markets: A Comparative Analysis", Directorate for Financial and Enterprise Affairs Competition Committee, DAF/COMP/WD(2014)77 (2014): 9.

21 See Ruwantissa Abeyratne, Competition and Investment in Air Transport, Switzerland: Springer International Publishing, 2016, 194-195. 
proposed by UNCTAD, the purpose of such law is to control and eliminate restrictive agreements, abuse of dominant positions, as well as M\&A amongst undertakings.

The Open Skies concept has changed the dynamic of airline competition, which was initially regulated under bilateral air services agreements (BASAs). Usually, the terms of BASAs regulate and limit market access behaviour regarding, amongst others: routes, frequencies, aircraft capacity and tariffs. These exclusive rights were only given on bilateral basis. However, the trends of liberalisation, which has brought substantial economic and traffic growth, changes the aviation market. While routes are still heavily negotiated and predetermined within air services agreements (ASAs) nowadays, frequencies and capacities are adopted on the basis of "open market access" allowing competition to be freed amongst airlines. ${ }^{22}$ That also comes with a challenge, that is, the absence of globally uniform conditions for airline competition. ${ }^{23}$

The International Civil Aviation Organization (ICAO), at the $38^{\text {th }}$ Session of its Assembly in 2013, adopted a resolution dealing with competition. ICAO Assembly Resolution A38-14 states that the Assembly "...urges member States to take into consideration that fair competition is an important general principle in the operation of international air services..." 24 and then requests the ICAO Council to establish a forum for enhancing cooperation, dialogue and information exchange regarding fair competition ${ }^{25}$ Further, the Assembly encouraged States to ensure that basic principles of fair and equal opportunity are adopted into national legislations. ${ }^{26}$

\subsection{The Competition Law in the European Union}

It is the belief of the EU that economic entities must have a level playing field on which to compete and that competition market conditions must be protected to ensure properly allocated resources as well as well a high level of consumer protection. ${ }^{27}$ The legal basis of EU competition law is found in the Treaty of the Functioning of the European Union (TFEU), particularly Article 101, 102, 107 and 108, which respectively regulate agreements and concerted practices that may restrict competition, abuse of dominant position, and State aid. Additionally, the regulatory control of M\&A control is regulated under EU Regulation 139/2004.

\subsubsection{Prohibition on Practices Affecting Competitions}

In essence, Article 101(1) of TFEU stipulates that any actions which negatively impact the internal market, shall be prohibited. Air law expert

${ }^{22}$ Frederico Bergamasco, "State Subsidies and Fair Competition in International Air Services: The European Perspective." Issues Aviation L. \& Pol'y15 (2015): 29-75

${ }^{23} \mathrm{Ibid}$., 30.

${ }^{24}$ International Civil Aviation Organization (ICAO), Doc 10022, III-6.

25 ICAO, Doc 10022, III-7.

26 Ibid., III-9.

${ }^{27}$ Speech of 15 September 2005 as cited in ibid.; See also Chris Townley, "Which Goals Count in Article 101 TFEU?: Public Policy and Its Discontents", European Competition Law Review 9 (2011):440-448. 
Pablo Mendes de Leon explains that those prohibited practices are: a form of collusion, either written in agreements between undertakings or associations of undertakings, or a form of cooperation that is not written in any agreements (concerted practice); behaviours that may affect trade between EU States; and behaviours that result in the distortion, restriction or prevention of competition in the EU market. ${ }^{28}$ Paragraph 3 of Article 101 allows for an exemption to the above-mentioned practices, providing that the economic benefits of a given practice outweigh the negative impact on $\mathrm{EU}$ competition.

Even though Article 101 does not specifically regulate the aviation industry, the definition of undertakings encompasses airlines. In Airfreight Cartel case decided by the European Commission on 17 March 2017, airlines conducting in actions prohibited under Article 101 are regarded to be breaching EU competition law and were thereby fined for their actions with respective waivers given to the first airlines who came forward and admitted the wrongdoing of price-fixing ${ }^{29}$

\subsubsection{Prohibition on Abuse of Dominant Position}

Article 102 of TFEU prevents the abuse of a dominant market position by an undertaking. The phrase 'dominant position' is not used or defined anywhere in TFEU but deemed to mean substantial market power. ${ }^{30}$ In a 1978 decision from the European Court of Justice, an interpretation of the term 'dominant position' is given as a position of economic strength created by an undertaking that enables the preclusion of competition, which establishes economic independence over customer, consumer, and its competitors. ${ }^{31}$

The fundamental goal of this Article 102 is to prevent monopolies, which limits competition in private industries that effects consumer interests and society in general. ${ }^{32}$ The dominant position of an undertaking is in itself not illegal, providing that such undertaking competes on the merits of its business and does not use its position to limit productions, market entrance, and the technical development of other undertakings, or imposing unfair prices upon consumers. ${ }^{33}$

As pointed out by Mendes de Leon, over the past two decades, there is little case law on the application of Article 102 in the aviation sector. The cases usually “... involve airline or airport behaviour, principally in relation to pricing of airport services...”. ${ }^{4}$

\subsubsection{State Aids}

28 Pablo Mendes de Leon, Introduction to Air Law, 10 th Ed., (Alphen aan den Rijn: Wolters Kluwer 2011), 102.

29 Case AT.39258 - Airfreight

30 Abeyratne, op.cit., p. 201.

31 United Brands v. Commission, Case 27/76 [1978] ECR 207 [1978]1 CMLR 429.

32 Ruwantissa Abeyratne, Competition and Investment in Air Transport, 200.

33 Ibid.; See also Case 85/76 Hoffman-La Roche para. 38.

34 Mendes de Leon, Introduction to Air Law, 105. 
Article 107 to 109 of TFEU regulates State aid. These Articles prohibit member States from financially aiding or giving resources to undertakings, given that such State involvement in a free market causes market distortion or threatens to distort competition by favouring a given undertaking or undertakings. However, State aid may be given, providing that such aid: does not adversely affect trading conditions; 35 has terms and conditions similar to that given by private investors who operate under normal market conditions; 36 and that aid is proportional for the purpose of restructuring or jump-starting a company. ${ }^{37}$

The EU has been applying this provision to air transport for twenty years, starting with the decision of the EU Commission on Belgian aid to its former airline Sabena, which was brought to attention in 1989. Prohibition on State aid to airlines, regardless whether it is privately or State-owned, has therefrom been applied to airlines that do not satisfy the 'exceptional measure' principle when they are given aid by a State. ${ }^{38}$ As a consequence, many EU flag carriers have gone bankrupt, including Sabena, Swissair, and Malev. 39

Nevertheless, the primary objective of the State aid provisions is to ensure the proper functioning of the Single European Market, including the 'level-playing field' that the EU has been trying to achieve. That concern is laid down in the 2014 State Aid Guidelines (SAG), which justifies certain categories of aid to regional airports and airlines, while still supressing the negative effects State aid brings to competitions if not given thoughtfully in line with Articles 107 to 109 TFEU.40

\subsubsection{Mergers and Acquisitions Control}

The stipulation of M\&A is laid down under EU Regulation 139/2004 on the Control of Concentration between Undertakings. This Regulation obligates undertakings conducting M\&A to notify the EU Commission, which the Commission has the power to either prevent, conditionally approve or simply approve. ${ }^{41}$ The obligation substantiated above is applied whenever the mergers and acquisitions have an EU dimension, that is: (i) in relation to ventures involving a worldwide turnover for over five billion euros; or (ii) community-wide turnover for over 250 million euros. ${ }^{42}$

\footnotetext{
35 TFEU, Art. 112(3).

36 Pablo Mendes de Leon, Introduction to Air Law, 117.

37 Ibid.
}

38 See Mendes de Leon, "Competition in International Markets: A Comparative Analysis". 118. "Exceptional measure allowing State aid to be approved by EU Commission, inter alia: (i) the establishment of a restructuring plan for undertakings which must be focused on the core of business of transport of passengers on the most profitable routes; (ii) the obligation of air carriers to contribute to the restructuring operation; (iii) the allowance of temporary restricting support only, limited in both amount and time; (iv) the obligation to pay back the loan given by the government; ( $v$ ) airline recapitalisation; and (vi) the 'one time last time' condition, meaning airline may only be funded by Member States once every ten years".

39 Sabena Case Decision (2001); Swissair (2001); Malev (2009).

40 Communication from the Commission - Guidelines on State aid to airports and airlines OJ C 99, 4.4.2014, 3-34

41 European Council Regulation (EC) No. 139/2004, Art. 4.

42 EC 139/2004, Art. 1. 
Since the adoption of this regulation, the EU Commission has assessed mergers among airlines within the EU and beyond. In most cases such mergers, when involving intra-EU carriers, were granted on the condition to surrender slot allocation at airports and decreasing frequencies to allow new players the opportunity to compete within the routes the merged airlines were previously exercising. ${ }^{43}$ This regulation also applies to $M \& A$ between EU and non-EU airlines as well as mergers of non-EU airlines flying in the EU, allowing the EU Commission to review mergers of United Airlines and USAir, Delta and PanAm, Singapore Airlines and Virgin, as well as Swissair and South Africa with EU M\&A regime.

\subsubsection{Realisation of Free Market Ensuring Equal Opportunities for Business Players}

As a supranational organisation, the EU has proven itself capable of establishing a successful internal market. EU competition law functions well and has set up a liberalised market with a high degree of freedom for undertakings to act within. ${ }^{44}$ The substantiation of EU Competition Law above shows decoupling of States and commercial interest, especially regarding State aid. The EU has made a regime that can develop remedies to mitigate what it considers as unfair actions or practices that may disrupt the liberal functioning of its internal market. That is of course in light of the fact that the legal framework is accompanied by sufficient enforcement bodies such as the EU Commission.

Historically, provisions for the enforcer of competition regulations in the EU has undergone several amendments. The EU competition regime has been enforced by its Director General for Competition (DG Comp), which was granted authority by EC Regulation No. $17 .{ }^{45}$ With its authority, DG Comp has implemented a centralised common competition regime, identified competition policy as a key factor to successfully establish the Single European Market, and concluded the 1989 Merger Control Regulation. ${ }^{46}$ The most recent reform for competition related matters is EC Regulation 1/2003, in which competition enforcement has been decentralised with a network of competition authorities in the EU working together in addition to courts of EU Member States. ${ }^{47}$

Its success in implementing and enforcing competition law, not only within the organisation but also in neighbouring countries, such as Switzerland, has given the EU a gravitas in discussions on the harmonisation of regional competition law. That said, discussion on the ASEAN competition regime below will have reference and comparison with EU competition law as explained above.

43 Mendes de Leon, Introduction to Air Law, 112.

44 Ibid., 121.

45 David J. Garber, "Two Forms of Modernization in European Competition Law." Fordham International Law Journal 31, no. 5 (2008): 1235-1265.

46 Michelle Cini and Lee McGowan, Competition policy in the European Union, (Pelgrave: Hampshire 2019), 19.

47 Ong, The Regionalisation of Competition Law and Policy within the ASEAN Economic Community, 47; Mendes de Leon, Introduction to Air Law, 103. 


\subsection{Identifying Fair Competition in ASEAN}

Having explained what practices are considered unfair in the EU, it is now time to learn how ASEAN defines what fair competitive practices are in its market.

\subsubsection{Unfair Competition as Identified in ASEAN Competition Guideline}

Much like the EU, ASEAN opts to identify what makes competition unhealthy to get a grasp on ensuring fair competition in its market. The ASEAN Competition Guidelines provide that the national competition laws ASEAN Member States should include the prohibition of: anti-competitive agreements; abuse of dominant position; anti-competitive mergers, and other restrictive trade practices. ${ }^{48}$ Those prohibitions were actually retrieved from the implemented competition laws in ASEAN Member States that have so far implemented and enforced its laws, which mirror most EU competition rules explained in the previous section.

The prohibited practices above are defined not too distinct from that of the EU. Though concerted practices as a form of collusion is not explicitly regulated in ASEAN, the provision does mention that prohibited agreements encompass formal and non-formal agreements. The abuse of dominant position, on the other hand, regulated in the majority of ASEAN Member States competition laws, has various definitions in each respective national competition regime. On anticompetitive mergers, while the laws in ASEAN countries provide minimum market share requirements and a turnover threshold above which merger should be notified, not all laws apply to mergers extraterritorially, as explained in the second section of this paper. 49

State aid is what actually highlights the differences between ASEAN and EU competition laws, as the EU has substantially regulated State involvement in free markets. In Southeast Asia, State aid may fall under 'other restrictive commercial practices', which is interpreted differently throughout the region. This missing element of competition law is due to the presence of State-owned companies in ASEAN countries that receive direct capital injection and are controlled by States. ${ }^{50}$

\subsection{Whether ASAM Can Operate Well under Collective National Competition Laws}

Over the past decades, aviation industries have experienced a spike in economic growth. The factors of such growth range from the conclusion of ASAs to capital injections from States to airlines and other players in the industry.

\footnotetext{
48 ASEAN Secretariat, ASEAN Regional Guideline on Competition Policy, (Jakarta: ASEAN Secretariat 2010), 6

49 ASEAN Secretariat, Handbook on Competition Policy and Law in ASEAN for Business 2017, (Jakarta: ASEAN Secretariat 2017).

50 See OECD, "the Case of Singapore and Other ASEAN Economies", in State-Owned Enterprises in the Development Process, OECD Publishing Paris (2015), https://doi.org/10.1787/9789264229617-5-en.
} 
MAAS, the first agreement establishing ASAM, provided open market access for all carriers from ASEAN on the basis of third, fourth and fifth freedom of passenger air traffic to all capital cities of ASEAN countries. MAFLAFS, liberating air cargo restrictions in ASAM, opens up access to international airports in all ASEAN countries with the same freedoms as with passenger traffic. Lastly, the MAFLPAS provides third, fourth, and fifth freedom for flights between capital and non-capital cities of ASEAN countries. These multilateral agreements are set to supersede current BASAs among Member States with predetermined frequencies and flight capacities. Moreover, all three agreements of ASAM collectively provide unlimited multiple airline designation with relaxed ownership and control rules. These liberalisations surely present consequences and changes to the current dynamics of international flights Southeast Asia.

\subsubsection{The Consequences of Liberalisation in ASAM}

With what can be learned in the EU, lifting predetermined frequencies and capacity constraints, not to mention the opening of more routes, would result in airlines behaving like other undertakings. Initially, because the above-mentioned elements that were predetermined in ASAs, market behaviours of international flight carriers in Southeast Asia fell outside the scope of competition law regimes. New liberal market rules might invite anticompetitive practices discussed in the previous chapter, providing that the ASEAN competition regime is not implemented on time with that of ASAM. Additionally, a new designation clause, which allow unlimited designations of airlines with relaxed ownership and control rules, might invite cross-border M\&A between airlines in the region. At present there is no telling what ASEAN cross-border M\&A might hold.

However, there is a carrier nationality clause containing of what is considered by aviation experts in the region as the gateway for an ASEAN Community Carrier. There are two options on how such carrier could be established, setting aside whether it is accepted by ASEAN countries to which the carrier such a status would be designated. Firstly, the airline could be established from scratch, meaning creating new airlines with majority ownership by nationals from ASEAN countries. Alternatively, existing airlines could merge together and operate under the same community flag. The latter of course is subject to M\&A control provisions in the region.

\subsubsection{Collective National Laws' Implementation for ASAM}

Practising collective competition laws only from domestic legislations is not the endgame of harmonising competition law in ASEAN Member States. As discussed in the previous chapter, ASEAN seeks to find common principles in the region and hopes to have it done by 2025 . However, as of now the competition regime in motion is the regime of that from each Member State. Instead of having supranational regulation that would converge domestic legislations, the future of ASEAN competition law will be built upon domestic legislation. In a way, if we see the end result, ASEAN will have a regional-level competition provisions structurally similar to the 
EU. Despite that, it has been brought to attention that the success of the European Single Market is not only because of the supranational legislation but also because of its effective regulatory implementation and enforcement. But mere harmonisation might not be sufficient to ensure fair competition in ASEAN.

\subsection{Contemplating the Ways Forward}

\subsubsection{Learning from EU Internal Aviation Market}

Learning from the EU would be a difficult task for ASEAN. As an organisation, ASEAN does not have a supranational body built into its structure. The absence of this results in the inability to impose uniform competition rules on all Member States. Moreover, it is the distinctive characteristic of ASEAN to do things the 'ASEAN Way', meaning that all Member States shall settle any differences by negotiating to reach a consensus. In addition, because of the principle of non-interference and respect for sovereignty embedded within its approach, ASEAN crystallised this consensus-based settlement mechanism into a multilateral agreement. ${ }^{51}$ On the other hand, the EU has its judicial body that gives jurisprudence to competition law as shown in the previous section.

The main difference between these two regional organisations is the supranational character of the EU. Unlike ASEAN, in which competition law is decentralised from States, the root of EU competition law comes from TFEU implemented domestically by national legislation in each EU Member State. The underlying reason to establish competition law in ASEAN and the EU is also different. ASEAN aims to achieve sustainable economy whereas the latter aims at consumers' welfare. ${ }^{52}$ Moreover, market integration in EU is perceived as the primary goal of its economic regulation, while ASEAN uses economic integration as a tool to invite direct foreign investment, growth and market competitiveness, rather than setting integration as its main goal. The differences substantiated above will hinder ASEAN from taking a leaf directly from the EU. Nevertheless, ASEAN should take a note that the system of the EU works for its internal market.

Josef Drexl argues that ASEAN might want to consider changing its way and adopt a supranational approach like the EU. He argues that competition law in the $\mathrm{EU}$ is underlined with a goal to guarantee the functioning of internal market. It minimises the possibility of undertaking to participate in anticompetitive practices via the lack of State jurisdiction. ${ }^{53}$ Further, he suggests that supranational law works better to ensure fair and equal opportunity for all undertakings compared to national laws. That is due to the application of the uniform rules throughout the region, which foreign investors find more attractive. ${ }^{54}$

${ }^{51}$ ASEAN, Protocol on the Enhanced Dispute Settlement Mechanism, signed on 29 November 2005.

52 Ong, The Regionalisation of Competition Law and Policy within the ASEAN Economic Community, 226.

${ }^{53}$ Ibid.

${ }^{54}$ Barbora Valckova, "EU Competition Law: A Roadmap for ASEAN?" EU Centre in Singapore, Working Paper No. 25 (2015): 6. 
The proposed idea might work well in theory. However, there are reasons why ASEAN refrains from adopting such a governance system. The core principle and the 'ASEAN Way' of dealing with things is one of the reasons. Adoption of a supranational law means that Member States need to give up their national sovereignty, because supranational law requires centralised decision-making coupled with national competencies. ${ }^{55}$ ASEAN, however, should not be the reason to negate the fact that the EU supranational competition law model works in regulating a regional internal market. Cherry-picking the best of EU law and combining it to ASEAN's regime to make a hybrid competition law, with centralised enforcement after common principles are set might be a start to a well-integrated market for aviation or other economic sectors.

The argument of the previous paragraph is not intended to suggest a question as to whether the current regime of ASEAN competition law is doomed to fail for the upcoming full realisation of ASAM. However, it is intriguing to hypothesise that departure from the ASEAN Way' and adopting the EU Way would work well in enforcing uniform competition rules. Nevertheless, daydreaming about what could be is not going to answer the competition issues within the South East Asia aviation market.

\subsubsection{The Role of International Comity in Competition}

Even though the plan to have harmonious enforcement of competition law by national competition authorities is already set in motion, this subchapter proposes an implementation of the concept of international comity to complement existing competition rules in ASEAN.

Comity historically arose from particular conflict of law issues in domestic jurisdictions. This is still the case today, along with its courteous younger diplomatic cousin 'comity of nations': 'a willingness to grant a privilege, not as a matter of right, but out of deference and good will', This form of comity has other forms such as "judicial comity", and "comity of nations" or international comity. ${ }^{56}$ Black's quotes two US judgements defining these forms of comity, showing that whereas the rich history of judicial comity is the principle in accordance with which the courts of one state or jurisdiction will give effect to the laws and judicial decisions of another, not as a matter of obligation, but out of deference and mutual respect', 57 a comity of nations is 'the recognition which one nation allows within its territory to the legislative, executive or judicial acts of another nation....'58 Given the power of sovereignty and non-binding character of comity, a comity of nations must be mutually beneficial, or else there is no reason for recognising another State extraterritorially. Contemporary legal literature accepts comity is generally not legally binding under international law, as Ulrich asserted, which has amounted to its unfettered conceptual

55 Ong, The Regionalisation of Competition Law and Policy within the ASEAN Economic Community, 230.

56 Bryan A. Garner and Henry Campbell Black, Black's Law Dictionary (St. Paul: MN West, 2009), 267.

57 Brown v Babbitt Ford, Inc (1977) 117 Ariz 192, 571 P.2d 689, 695.

58 Nowell v Nowell (1966) Tex Civ App 408 S.W.2d 550, 553. 
relationships drawn with public and private international law, diplomacy, morality, and so forth. Paul writes that this the advantage of comity, for it flexible as a non-binding principle yet beneficial to States if exercised. 59

Comity is of benefit to any competition authority dealing with market actors from outside their jurisdiction, which is ever-more important given the growth in international trade in goods and services. Countries of a comity have the advantage of consulting more experienced competition regulators, requesting information on a company of interest from a relevant competition authority, or coordinating investigation efforts that are mutually beneficial to the objectives of coordinated authorities. A prominent example of comity here is the International Competition Network (ICN): an 'informal venue' for all willing competition authorities to exchange information and build consensus, founded in October 2001 by officials from across the world including inter alia the EU, US, Canada, Japan, the United Kingdom and Zambia. ${ }^{60}$ ICN is a comity of national competition bodies commonly concerned with international market competition and its effects on national economies. There are no obligations to join ICN or duties as a member thereto, as the common interest in consulting other competition officials, drafting recommendations and exchanging information is a mutual incentive to cooperate amongst nodes in the network with a common interest.

In ACAP 2025, a plan on gathering all competition authorities to exchange information and work harmoniously among each other has already been accommodated. As it is ASEAN Way of respecting the sovereignty of each Member State, the concept of international comity in enforcing competition law to ensure fair competition is the most likely scenario that would be easily accepted by in ASEAN. The primary role of comity for ASAM is to fill the void of competition regulations in AEC, 61 recognising the positions and strengths of every Member State based on the common interest of establishing a highly competitive airline industry in the region.

\section{Conclusion}

Though the competition laws in ASEAN lack uniformity, their rapid development should be applauded. Since the creation of AEC Blueprint and Competition Action Plan in 2005, nine of ASEAN Member States have developed and implemented legislations on competition rules, even though Cambodia is still in the process of drafting. This development is accelerated by the initiation of ASAM in 2010. However, ASAM also needs comprehensive and enforceable competition laws and policies in order to function well. As compared to EU competition law, it should be admitted that having a supranational characteristic may be to the benefits of making enforcement easier, but ASEAN has its own way of decision-making which is different from that of the EU.

59 Joel R. Paul, "The Transformation of International Comity," Law and Contemporary Problems 71, no. 3 (2008): 19-20.

60 International Competition Network [ICN], 'About' https://www.internationalcompetitionnetwork.org/about/

${ }^{61}$ Henri Wassenbergh, "The Decision of the ECJ of 5 November 2002 in the 'Open Skies' Agreements Cases." Air and Space Law 28, no. 1 (2003): 29. 
The existing regime of ASEAN competition law might not be sufficient to accommodate the liberalised regime of ASAM, as is realised by all Member States. Therefrom a plan is in motion to establish a comprehensive mechanism to implement and enforce competition laws throughout the region. In addition to having a regional level enforcer, the concept of international comity can play a major role in filling the absence of binding regional level regulation and enforcement. Looking at the development of ASEAN competition laws this past a decade, without departing from its core principle, ASEAN will overcome the obstacles in the future of transitioning to a fully liberalised aviation market.

\section{Acknowledgement}

This article is an advanced version of an essay composed by author during his study at Leiden University, Advanced LLM in Air and Space Law Programme in 2019, on Air Transport Competition Law and Policy. The author would like to express a great honour to Prof. Pablo Mendes de Leon who taught this course. Additionally, the author would like to express his gratitude to Kyran Grattan and Anak Agung Mia Intentilia for their assistance and contribution to the composition of this paper. Argument and opinion contained in this article is an academic view of the author and do not necessarily link to author's affiliation.

\section{BIBLIOGRAPHY}

\section{Books}

Abeyratne, Ruwantissa. Competition and Investment in Air Transport. Switzerland: Springer International Publishing, 2016.

Bhagwati, Jagdish and Robert Hudec. Fair Trade and Harmonization: Economic Analysis. Cambridge: The MIT Press, 1996.

Cini, Michelle and Lee McGowan. Competition policy in the European Union. Hampshire: Pelgrave, 2019.

Garner, Bryan A. and Henry Campbell Black. Black's Law Dictionary. St. Paul: MN West, 2009.

Klip, Andrew and H. van der Wilt. Harmonisation and Harmonising Measures in Criminal Law. van Wetenschappen: Royal Netherlands of Science, 2002.

Mendes de Leon, Pablo. Introduction to Air Law. 10 th Ed. Alphen aan den Rijn: Wolters Kluwer, 2011.

Nugraha, Ridha Aditya. State Aid for Pioneer Routes Under PSO in Indonesia Against the Tide within ASEAN Open Skies?. Mauritius: Lambert Academic Publishing, 2017.

Ong, Burton. The Regionalisation of Competition Law and Policy within the ASEAN Economic Community. Cambridge: Cambridge University Press, 2018. 
Soekanto, Soerjono and Sri Mamudji. Penelitian Hukum Normatif, Suatu Tinjauan Singkat. Jakarta: Raja Grafindo Persada, 2007.

\section{Journal Articles}

Bergamasco, Federico. "State Subsidies and Fair Competition in International Air Services: The European Perspective." Issues Aviation L. \& Pol'y15 (2015): 29-75.

Freeman, Peter. "Is Competition Everything." Competition Law Journal 7, no. 3 (2008): 214-225.

Garber, David J. "Two Forms of Modernization in European Competition Law." Fordham International Law Journal 31, no. 5 (2008): 1235-1265.

Lee, Casse and Yoshifumi Fukunaga. "ASEAN Regional Cooperation on Competition policy." Journal of Asian Economics, 35 (2014): 77-91.

Luu, Huong Ly. "Regional Harmonization of Competition Law and Policy: An ASEAN Approach." Asian Journal of International Law 2, no. 2 (2012): 291-321,: https://doi.org/10.1017/S2044251312000124

Masron, Tajul Ariffin. "Promoting Intra-ASEAN FDI: The Role of AFTA and AIA." Economic Modelling $31 \quad$ (2013): 43-48. https://doi.org/10.1016/j.econmod.2012.11.050

Paul, Joel R. "The Transformation of International Comity." Law and Contemporary Problems 71, no. 3 (2008): 19-38.

Siadari, Devi Lucy Y., and Koki Arai. "International Enforcement of ASEAN Competition Law." Journal of European Competition Law \& Practice 9, no. 5 (2018): 328-335. https://doi.org/10.1093/jeclap/lpy009

Silalahi, Udin. "Accelerating the Development of ASEAN Competition Culture." XII:2 L. Rev. (2012).

Silalahi, Udin. "The Harmonization of Competition Laws towards the ASEAN Economic Integration." JE Asia \& Int'l L. 10, no. 1 (2017): 117-137.

Spitz, Laura. "The gift of Enron: An opportunity to talk about capitalism, equality, globalization, and the promise of a North-American charter of fundamental rights." Ohio St. LJ 66 (2005): 315-396.

Townley, Chris. "Which Goals Count in Article 101 TFEU?: Public Policy and Its Discontents", European Competition Law Review 9 (2011):440-448.

Wassenbergh, Henri. "The Decision of the ECJ of 5 November 2002 in the 'Open Skies' Agreements Cases." Air and Space Law 28, no. 1 (2003): 19-31.

\section{Legal Documents}

ASEAN. The 2005 Protocol on the Enhanced Dispute Settlement Mechanism.

Brunei Darussalam. Competition Order of 2015.

ASEAN. Charter of the Association of South-East Asian Nations.

Convention on the International Civil Aviation (1944)

European Council Regulation (EC) No. 139/2004

Kingdom of Cambodia. Draft Competition Law of 2016.

Kingdom of Thailand. Trade Competition Act of 1999.

Lao People's Democratic Republic. Competition Law of 2016.

Malaysia. Competition Act of 2010.

Republic of Indonesia. Law Number 5 of 1999 on the Ban of Monopolistic Practices and Unfair Business Competition 
Republic of Singapore. Competition Act of 2004.

Republic of the Philippines. Competition Act 2015.

Republic of the Union of Myanmar. Law No. 9 of 2015 on Competition.

Socialist Republic of Vietnam. Competition Law of 2005.

Treaty of the Functioning of the European Union

\section{Other Documents}

Amirullah, Adli. "Economic Benefits of ASEAN Single Aviation Market", Institute for Democracy and Economic Affairs, Policy No. 56 (2018).

ASEAN Secretariat, ASEAN Competition Action Plan 2025.

ASEAN. Bali Concord II: http://www.asean.org/news/asean-statementcommuniques/item/ declaration-of-asean-concord-ii-bali-concord-ii3.

International Civil Aviation Organisation, Doc 10022.

Mendes de Leon, Pablo. "Competition in International Markets: A Comparative Analysis." Directorate for Financial and Enterprise Affairs Competition Committee, DAF/COMP/WD(2014)77 (2014).

OECD, "the Case of Singapore and Other ASEAN Economies", in StateOwned Enterprises in the Development Process, OECD Publishing Paris (2015), https://doi.org/10.1787/9789264229617-5-en

Valckova, Barbora. "EU Competition Law:A Roadmap for ASEAN?" EU Centre in Singapore, Working Paper No. 25 (2015).

Kingdom of Cambodia Nation Religion King. Draft Law on Competition of Cambodia. Version 5.7. https://aseancompetition.org/file/pdf_file/Draft \%20Law\%20on\%20Competition\%20 2018.pdf

\section{Case laws}

Case AT.39258 Airfreight Cartel, European Commission.

(United Brands v. European Commission), The Court of Justice of the European Communities Case 27/76 [1978] ECR 207 [1978]1 CMLR 429.

Website Content

International Competition Network [ICN], 'About'.

https://www.internationalcompetitionnetwork.org/about/ 